STANISŁAW BITKA

Instytut Filmu, Mediów i Sztuk Audiowizualnych Uniwersytet im. Adama Mickiewicza w Poznaniu
Images vol. XXVI/no. 35

Poznań 2019 ISSN 1731-45OX

\title{
Bunt i nostalgia. Filmy dokumentalne o festiwalu $w$ Jarocinie
}

\begin{abstract}
Bitka Stanisław, Bunt i nostalgia. Filmy dokumentalne o festiwalu w Jarocinie [Rage and nostalgia. Documentaries about Jarocin festival]. „Images” vol. XXVI, no 35. Poznań 2019. Adam Mickiewicz University Press. Pp. 171-181. ISSN 1731-450X. DOI 10.14746/i.2019.35.10.

The aim of the article is to present and attempt to classify documentary films about the Jarocin music festival. The films are conventionally divided into those shot during the 1980s editions and those created in our century, which describe the festival in retrospect. By analyzing selected works, the author draws attention to whether and how the approach to the subject and the form of the film change over the years.
\end{abstract}

KEYWORDs: Jarocin, rockumentary, music documentary, punk

Festiwal w Jarocinie[1] (a zwłaszcza jego edycje $\mathrm{z}$ lat osiemdziesiątych) stał się symbolem buntu. Buntu nie tylko w wymiarze politycznym, ale przede wszystkim estetycznym, związanym bardzo mocno z szeroko rozumianą muzyką alternatywną. W Jarocinie grano zarówno muzykę punk-rockową, jak i heavy metal czy reggae. Jak wspominał Robert Brylewski (między innymi Brygada Kryzys, Izrael, Armia): „Skumulowały się [tam] aspekty antypaństwowe, mistyczne poczucie odseparowania. Każdy zespół prezentował własny punkt widzenia i panowała totalna różnorodność” [2]. W latach osiemdziesiątych była to największa tego typu impreza za „żelazną kurtyną”. Nic dziwnego, że Jarocin poza rzeszami muzyków i entuzjastów interesował ówczesną Służbę Bezpieczeństwa, socjologów, etnografów, dziennikarzy, wreszcie filmowców. W związku z powyższym festiwal w Jarocinie został opisany z różnych perspektyw: „operacyjnej” (działaniom SB i ich dość kuriozalnym wynikom, poświęcona jest publikacja Jarocin w obiektywie bezpieki[3]), naukowej (warto w tym momencie przy-

[1] Historia festiwalu sięga lat siedemdziesiątych. Wówczas impreza odbywała się pod nazwą Wielkopolskie Rytmy Młodych, a na początku lat osiemdziesiątych Ogólnopolski Festiwal Młodej Generacji, następnie Festiwal Muzyków Rockowych (dla ułatwienia dalszych rozważań, w artykule będę używał domyślnej formy festiwal. $Z$ dostępnej literatury i materiałów filmowych wynika, że największym uznaniem publiczności cieszyły się edycje ze środkowych lat osiemdziesiątych. Po transformacji odbyły się jeszcze cztery edycje festiwalu, których jakość stopniowo spa- dała, a impreza stała się miejscem zamieszek (ostatni skończył się poważnymi stratami, które poniosło miasto). W 2000 roku jednorazowo odbył się Start Festiwal Jarocin, w 2005 Jarocin PRL Festiwal. Od tego czasu festiwal odbywa się corocznie, jednakże na festiwalowej mapie Polski nie jest już tak znaczącą imprezą jak w latach osiemdziesiątych.

[2] R. Brylewski, R. Księżyk, Kryzys w Babilonie, Kraków 2012, s 231.

[3] K. Lesiakowski, P. Perzyna, T. Taborek Jarocin w obiektywie bezpieki, Warszawa 2004. 
wołać projekt Jarocin Re-Study realizowany przez „Czas Kultury”[4]) oraz „fanowskiej”. Wspomnienia $\mathrm{z}$ festiwalu zajmują istotne miejsce w książkowych autobiografiach muzyków: Soul Side Story Tomasza Budzyńskiego czy cytowany wyżej Kryzys w Babilonie Roberta Brylewskiego i innych. Wśród licznych publikacji najbardziej interesującym, zarówno dla fana, jak i badacza, źródłem informacji jest trzytomowy zbiór rozmów Grunt to bunt, na który składa się kilkadziesiąt rozmów $\mathrm{z}$ artystami występującymi w Jarocinie i z całą gamą luźno powiązanych z festiwalem postaci, od milicjantów po duchownych. Fragmenty tych rozmów zostały przedrukowane w obszernym albumie Pokolenie J8 Jarocin '80-'89. Ponadto od 2014 roku w Jarocinie funkcjonuje Muzeum „Spichlerz Polskiego Rocka”. Jednym z autorów treści wystawy jest Leszek Gnoiński, dziennikarz, pisarz, a także reżyser omawianego w niniejszym artykule filmu Jarocin. Po co wolność (2016).

W centrum moich zainteresowań nie jest sam festiwal (choć oczywiście nie da się od niego uciec), ale właśnie jego filmowe reprezentacje. Jestem przekonany, że ze wszystkich dostępnych materiałów to właśnie film - z oczywistych powodów - jest najlepszym źródłem wiedzy o festiwalu. Może przedstawić bowiem zarówno narrację historyczną, jak i samą istotę festiwalu, czyli muzykę. Od lat osiemdziesiątych do dziś powstało ponad kilkanaście obrazów dokumentalnych (filmów krótko- i pełnometrażowych, telewizyjnych oraz odcinków seriali), których głównym tematem jest Jarocin, oraz ogromna ilość materiałów amatorskich (wybrana filmografia znajduje się na końcu artykułu). Pod koniec krótkometrażowego Filmu o pankach (1983) młodzi wówczas członkowie grupy Dezerter stwierdzają, że nie da się zrobić dobrego filmu o środowisku punk-rockowym (o ironio, ci sami muzycy wystąpili potem w wielu filmach dokumentalnych próbujących uchwycić to zjawisko). Buńczuczne stanowisko młodych muzyków można interpretować dwojako. Po pierwsze, punk jest zjawiskiem nieopisywalnym, po drugie, kino dokumentalne jako takie nie jest w stanie oddać jego natury. W podobnym duchu wypowiedział się brytyjski dziennikarz Simon Reynolds w eseju poświęconym rockowym filmom dokumentalnym i muzeum:

Mój naczelny problem przy muzeach rockowych stanowi punk, ów uskok w dziejach rocka, który odesłał „starą falę” na śmietnik Historii. Czy taki apokaliptyczny przełom da się wcisnąć w archiwalny system fiszek i zachować jego istotę, jego brutalną prawdę[5]?

Nasuwają się pytania: czy buntownicza, alternatywna muzyka przełożyła się na formę filmową; skąd aż takie zainteresowanie festiwalem, a co za tym idzie: czy temat nie został wyczerpany?

Ze względu na szeroki obszar badawczy pozwolę sobie na dość arbitralny wybór omawianych filmów. Sama formuła jest w wielu dzie-

[4] <http://czaskultury.pl/czytanki/jarocin-restudy/> [dostęp: 10.01.2019].
[5] S. Reynolds, Retromania. Jak popkultura żywi się własna przeszłością, przeł. F. Łobodziński, Warszawa 2018, s. 45. 
łach bardzo zbliżona i nie widzę potrzeby poddawania wszystkich filmów szczegółowej analizie. Filmy o Jarocinie z jednej strony wpisują się $\mathrm{w}$ ramy rockumentaries, $\mathrm{z}$ drugiej zaś, ze względu na specyfikę samego festiwalu i kontekstów polityczno-społecznych, mimochodem wychodzą poza ramy podgatunku. Stają się swoistym zapisem stanu ducha młodzieży lat osiemdziesiątych i okresu transformacji. W słowniku Marka Hendrykowskiego pod hasłem film rockowy czytamy: „odmiana gatunkowa filmu muzycznego o charakterze fabularnym lub dokumentalnym (ang. rock documentary), którego dominantą kompozycyjną jest muzyka rockowa"[6]. Trzeba podkreślić, że w historii tego jakże popularnego podgatunku kina dokumentalnego to właśnie filmy nakręcone na wielkich festiwalach, takie jak Monterey Pop (1968) D.A. Pennebakera, a zwłaszcza Woodstock (1970) Michaela Wadleigha, walnie przyczyniły się do jego popularności[7].

Bill Nichols, analizując historię kina dokumentalnego, zaproponował w jego obrębie podział na sześć typów: poetycki, objaśniający, uczestniczący, obserwacyjny, refleksywny i performatywny[8]. Autor wyraźnie zaznacza, że typy te mogą się przenikać. Filmografia dotycząca festiwalu w Jarocinie wpisuje się, w mniejszym lub większym stopniu, w każdy z wyżej wymienionych typów, $\mathrm{z}$ wyraźnym naciskiem na typ uczestniczący, o którym tak pisze Nichols:

Filmowiec wychodzi spod płaszcza komentarza voice-over, odchodzi od poetyckiej medytacji, schodzi z pozycji muchy na ścianie i staje się aktorem społecznym, (niemal) tak jak wszyscy inni. (Niemal - ponieważ filmowiec zachowuje kamerę, a co za tym idzie, pewien stopień potencjalnej władzy i kontroli nad zdarzeniami) [9].

W przeciwieństwie do festiwali organizowanych na zamówienie telewizji, jak Sopot czy Opole, Jarocin odbyłby się niezależnie od obecności kamery. Należy zatem przypuszczać, że zarejestrowane przez kamerę wydarzenia (nie licząc wywiadów), takie jak koncerty czy życie podczas festiwalu, nie są reżyserowane i pokazane $\mathrm{w}$ takim stanie, w jakim wyglądałyby bez obecności filmowców.

Chronologicznie pierwszy, krótkometrażowy Jarocin 82 (1982) to film, w którego prologu eksplicytnie zostaje wyrażona teza: młodzież nie ma żadnych perspektyw, jedyna nadzieja jest w muzyce. Intuicję reżysera, Pawła Karpińskiego, potwierdzają badania przeprowadzone podczas kolejnych edycji. „W Jarocinie królowała muzyka i to właśnie dla niej ściągała młodzież z całego kraju[10]" - pisze Mirosław Pęczak.

Tu i teraz. Jarocin w latach osiemdziesiątych i w okresie transformacji Sam reżyser po latach odpowie:

[6] M. Hendrykowski, Słownik terminów filmowych, Poznań 1994, s. 256.

[7] M. Brendan, Rockumentary Style \& Sound in a Documentary Genre, Montreal 2011, s 181. [8] Zob. B. Nichols, Typy filmu dokumentalnego, przeł. M. Heberle i D. Rode, [w:] Metody dokumental- ne w filmie, red. D. Rode, M. Pieńkowski, Łódź 2013, s. $13-45$.

[9] Ibidem, s. 28.

[10] <http://czaskultury.pl/content/uploads/2015/12/ MPeczak_BadaniaJarocina1983_1984.pdf> [dostęp: 10.01.2019]. 
Teza tego filmu była taka: Jest miejsce, gdzie następuje zespolenie przyjeżdżających tam ludzi i tych, którzy występują na scenie. Oni chcą tego samego, mówią to samo. To była taka oaza wolności w tym zniewolonym kraju[11].

Narracja - co będzie typowe również dla późniejszych odsłon zachowuje chronologię samego festiwalu. Na początku widzimy serię ujęć z przyjazdu młodzieży na stację, życie na polu namiotowym, wreszcie - koncerty. Kończący film wywiad dzieje się rankiem po festiwalu. Co znamienne, rozmówcami reżysera są przeważnie nie muzycy, ale widzowie - przede wszystkim młodzież. Operator w kilku miejscach pozwala sobie na eksperyment: w jednym momencie potrząsa kamerą w rytm muzyki, w innym przyspiesza bieg taśmy. W eksperymentalnej formie są również utrzymane napisy końcowe: są po prostu napisane markerem na plakacie, który jest ukazany w ekstremalnych zbliżeniach. Nawiasem mówiąc, ten zapewne wynikający z niskiego budżetu zabieg znakomicie wpisuje się w punkową estetykę.

Paweł Karpiński zrealizował film fabularny To tylko rock (1984), który również koncentruje się na polskiej muzyce rozrywkowej i alternatywnej lat osiemdziesiątych. Fabuła skupia się na losach Sylwii (Grażyna Trela), wokalistki zespołu Krzyk, która dostaje propozycję rozpoczęcia kariery solowej pod okiem autora tekstów (Zdzisław Wardejn), tłem są dosyć stereotypowo ukazane kulisy i patologie ówczesnego showbusinessu. Finał odbywa się podczas festiwalu w Gradowie, podczas konkursu na Młodzieżowy Przebój Ro(ck)ku. Aluzja do festiwalu w Jarocinie jest bardzo czytelna (plenery zostały nakręcone właśnie w Jarocinie). W filmie możemy zobaczyć fragmenty występów takich grup jak Dezerter, Rejestracja, Mech, będącą u szczytu sławy grupę Lady Pank czy nawet brytyjski nowofalowy zespół Clasix Nouveaux.

Wśród filmów z lat osiemdziesiątych najbardziej wyróżnia się Fala (1986) w reżyserii Piotra Łazarkiewicza - ten pełnometrażowy film nie tylko odstaje pod względem warsztatowym i rozmachem, z jakim został nakręcony, ale stał się punktem odniesienia dla wielu kolejnych utworów. Ekspozycja Fali przypomina tę z filmu fabularnego: ukazana w planie ogólnym i zbliżeniu ulica w deszczową noc ma aurę filmu noir. Kolejne ujęcia o wschodzie słońca ukazują wieś budzącą się do życia: gdzieś widać motor, gdzieś jedzie traktor. Punkowcy, którzy pojawiają się nagle podczas ujęć na las, wyglądają, dosłownie, jak ciekawy okaz przyrody. Pierwszy wywiad słychać dopiero w szóstej minucie. Twórcy Fali rozmawiają zarówno z młodzieżą (publicznością) i artystami, jak i z lokalnymi władzami, milicją oraz działaczami. Wypowiedzi tych drugich, w których nie da ukryć się sztuczności (spowodowanej zapewne $\mathrm{z}$ jednej strony stresem związanym z obecnością kamery, z drugiej zaś treścią samej odpowiedzi), przedstawiają festiwal w samych superlatywach. Rozmowy z publicznością czy z artystami mają bardziej swobodny,

[11] <http://www.jarocin-festiwal.com/filmy/jaro-

cin82.html> [dostęp: 10.01.2019]. 
luźny charakter. Reżyser, zamiast o wrażenia z festiwalu, pyta o przyszłość. Jedynym wspólnym mianownikiem bardzo różnych odpowiedzi podobnie jak w przypadku poprzedniego filmu - jest muzyka.

Filmując rzeczywistość festiwalu oraz samego miasteczka, operator kręci zarówno w szerszych planach (kilkukrotnie wykorzystuje ujęcia z kranu), jak i w bliższych - pojawiają się ujęcia z ręki. Operator, Andrzej Wolf wyreżyserował później Jarocin 87 - reportaż z kolejnej edycji. Film jest o tyle ciekawy, że stał się przyczynkiem do filmu Jarocin 87 - podróż $w$ czasie, o którym piszę w dalszej części artykułu. $\mathrm{W}$ jednym z początkowych wywiadów widzimy krótką przebitkę na pracującego operatora. Reżyser kilkukrotnie wypowiada się zza kamery (nie do widza, ale do swego rozmówcy), w kilku momentach widać i słychać zakłócenia. Świadczy to o tym, że wszelkie niedociągnięcia są świadomym wyborem, a nie błędem warsztatowym. Dominantę filmu stanowią koncerty. Rzuca się w oczy różnorodność, o której mówił Robert Brylewski. Po koncercie punkowej Moskwy słyszymy reggae’owy Izrael, potem awangardowy Zilch czy heavy metalowy Kat. Sekwencje $\mathrm{z}$ koncertów charakteryzują relatywnie długie ujęcia. Spowodowane jest to zapewne ograniczeniami technicznymi (liczba kamer, oświetlenie), ale dzięki temu daje możliwość skupienia się na artyście i słowach. Nie licząc żartobliwego utworu grupy Dzieci Kapitana Klossa, większość piosenek wykorzystanych w filmie ma charakter protest songów.

Jednym z ostatnich utworów, jaki słyszymy podczas Fali, jest Moja krew z repertuaru Republiki. Utwór ten został wykorzystany w kolejnym filmie, stając się jednocześnie inspiracją dla tytułu. Nakręcony na zlecenie BBC film Moja krew, twoja krew jest z założenia nastawiony na innego odbiorcę. Choć opiera się na podobnym schemacie (połączenie wywiadów z utworami muzycznymi), obydwa poziomy są realizowane w inny sposób. Treść wywiadów podejmuje problem przez pozostałe filmy marginalizowany, mianowicie ówczesną sytuację finansową polskich muzyków. Przepytywani muzycy i działacze zwracają się do gości zza granicy, tłumacząc konteksty społeczne. Dzielą się entuzjazmem, ale także wylewają frustracje. „Wkurza nas jedna rzecz, że taki chłopaczek na Zachodzie bierze pieniądze od mamy czy taty i idzie do sklepu po gitarę Fendera, na którą tutaj nie mogą sobie pozwolić nawet profesjonaliści" - opowiada jeden z rozmówców. W dosyć emocjonalnej relacji dla magazynu „Non Stop”, żali się Paweł Sito: „Festiwal rejestrowała ekipa BBC. Czasami czułem się po prostu zażenowany dyletanctwem, poziomem, zachowaniem się tych, po których spodziewać można się było czego innego"[12]. Wykonania utworów muzycznych z festiwalu uzupełnione są wideoklipami, które ekipa filmowa zrealizowała już po jego zakończeniu. Tym samym w filmie znalazł się prawdopodobnie jedyny audiowizualny zapis nowofalowej odsłony legendarnej grupy Siekiera $\mathrm{z}$ fragmentem piosenki Ludzie Wschodu.

[12] P. Sito, Centralne dożynki, „Magazyn Muzyczny" 1986, nr 9 (331); <http://www.jarocin-festiwal. com/1986/mm8609.html> [dostęp: 10.03.2019]. 
W sierpniu 2011 do muzeum w Jarocinie trafił amatorski film Po drugiej stronie rampy (1984) [13] zrealizowany przez Wiesława Szlachciaka. Film nakręcony w 1984 na taśmie Super 8 w roku 2016 został zdigitalizowany oraz na nowo zmontowany i udźwiękowiony. Paradoksalnie dzięki temu, że na filmie nie została nagrana ścieżka dźwiękowa na żywo (w zdigitalizowanej wersji słychać dostępne na open source utwory rockowe), obraz ten daje możliwość obserwacji z dystansu, bliższej kinu bezpośredniemu, perspektywy „muchy na ścianie”. Struktura filmu wciąż przypomina poprzednie; na ekranie widać kolejno: miasto, tłum idący na festiwal, wreszcie same koncerty. Ten niepozorny utwór zawiera jedną z najbardziej immersyjnych sekwencji tańca pogo. Podobno Szlachciakowi asystowało dwóch ochroniarzy, a zdjęcia wykonywała jego żona Krystyna, siedząca mu „na barana”[14].

Festiwal w Jarocinie stał się również przedmiotem zainteresowania Józefa Robakowskiego. Awangardowy twórca zrealizował w Jarocinie teledysk zespołu Moskwa do piosenki Powietrza!, czy wideo Dziewczyny $z$ Jarocina (1986). Z naszego punktu widzenia najciekawszym będzie obraz: Tilt. Jarocin Moje Oko (1986). Robakowski zrobił bardzo prostą rzecz: podczas koncertu grupy Tilt zamiast skierować obiektyw kamery w stronę zespołu, obrócił ją na widownię. Owszem w pozostałych filmach również mamy całe sekwencje, w których widać twarze fanów w ekstazie, natomiast to, co gdzie indziej stanowi dodatek, Robakowski traktuje tak, by stanowiło przedmiot jego dzieła. W niektórych ujęciach widzimy kilka głów, w innych fotografa, w kolejnych fanów pod barierkami. Alicja Cichowicz porównuje działalność Robakowskiego do łowcy:

W „Tilcie...” (1986) kamera najpierw skanuje przestrzeń, prześlizguje się po uczestnikach koncertu w Jarocinie i szuka trofeów. Wyposażona w zoom, widząc więcej niż oko, pozwala łowcy śledzić swą zwierzynę. Jej spojrzenie jest baczne, intensywne. Wybiera ludzi zachowujących się najbardziej swobodnie, pewnych siebie i... zastyga w bezruchu[15].

Wydaje się, że Robakowskiego średnio interesuje sam koncert. Jest bardziej zainteresowany zachowaniem człowieka, który, zdając sobie sprawę, że jest obserwowany, czuje się w pewnym sensie bezradny. Najlepiej to uwidacznia sekwencja, podczas której kamera śledzi fotografa: $\mathrm{w}$ momencie, kiedy ten zdaje sobie sprawę $\mathrm{z}$ tego, że jest śledzony, stara się zachowywać naturalnie, pali papierosa, stroi miny.

Miłośnicy festiwalu, twórcy portalu Jarocin-festiwal.com rekomendują wyżej omawiane filmy Fala i Moja krew, twoja krew jako najbardziej wierne obrazowi, w przeciwieństwie do filmów telewizyjnych, którym zarzucają szukanie taniej sensacji[16]. Do tego typu filmów można by zaliczyć utwór Franciszka Trzeciaka Diabelskie

[13] <https://www.youtube.com/ watch?v=YpoDKXY3TE8> [dostęp: 10.03.2019]. [14] <https://kultura.onet.pl/muzyka/wiadomosci/ znaleziono-niepublikowany-film-z-jarocina-84/ dfqcqk9> [dostęp: 10.03.2019]..
[15] A. Chichowicz, <http://www.szklarniaszkolyfilmowej.pl/wystawa/25> [dostęp: 10.03.2019]. [16] <http://www.jarocin-festiwal.com/filmy/filmy. html> [dostęp: 10.03.2019]. 
nasienie. Film ten, w myśl typologii Nicholsa, należy uznać za objaśniający. Poza kilkoma wywiadami z przypadkowymi uczestnikami Festiwalu film składa się z podobnych do wcześniejszych wersji ujęć, jednakże dominantę stanowi ustny komentarz. „W przeciwieństwie do tradycyjnego rozłożenia akcentów w filmie, obrazy odgrywają tu rolę pomocniczą. Ilustrują, wyjaśniają, dopełniają lub stoją w kontrze do tego, co jest mówione"[17]. Komentarz Trzeciaka skupia się na stronie obyczajowej. Abstrahując od błędów merytorycznych, wręcz razi stronniczością.

Telewizyjny reportaż Jarocin. Czapka dla skina (1990) niewiele różni się od wcześniejszych wersji: ujęcia z miasta, rozmowy z muzykami i ze zwykłymi mieszkańcami Jarocina, zmontowane $\mathrm{z}$ fragmentami koncertów (między innymi grup Proletariat, Armia czy Big Cyc). Zmiany zachodzą w samym festiwalu: jak zauważa Tomasz Lipiński (Tilt), czas, w którym Jarocin był jedynym miejscem, gdzie młodzież mogła się czuć wolna, się skończył. Pod koniec filmu udokumentowane są pierwsze sprzeczki publiczności z organizatorami.

Istotę filmów $\mathrm{z}$ lat osiemdziesiątych trafnie uchwyciła Jadwiga Hučkova:

Filmy na ich [festiwali] temat były czymś więcej niż zapisem występów i atmosfery im towarzyszącej - przekazywały obraz oczekiwań młodzieży, która nie potrafi się odnaleźć w żadnej z form proponowanych przez kulturę oficjalną[18].

W obfitej filmografii na temat festiwalu w Jarocinie dosyć szczególne miejsce zajmują dwa filmy, odcinki seriali, które nie skupiają się na muzyce, ale na działalności Służby Bezpieczeństwa. Wydział śledczy IPN: Jarocin (2008) to swoisty komentarz do przywołanej wyżej publikacji Jarocin $w$ obiektywie Bezpieki. W archiwach łódzkiego IPN zupełnie przypadkowo odnaleziono materiały operacyjne Służby Bezpieczeństwa $\mathrm{z}$ dokonanej na festiwalu infiltracji subkultur młodzieżowych. Film składa się z sekwencji, podczas których kamera w ekstremalnym zbliżeniu ukazuje strony książki, na których widać zdjęcia i skany dokumentów. Narrator $\mathrm{z}$ offu czyta fragmenty dokumentów, z których jasno wynika, że SB nie dość, iż nie miało pojęcia na temat subkultur, to jeszcze wymyśliło swój system, w którym istniały różnego rodzaju jednostki bojowe punkowców, metalowców itp. Film wzbogacony jest wywiadami między innymi ze znanym dziennikarzem Bartkiem Chacińskim i kulturoznawcą Mirosławem Pęczakiem, którzy punktują różnego rodzaju absurdy, znalezione w dokumentach. W podobnym duchu utrzymany jest odcinek serialu $Z$ filmoteki Bezpieki: Jarocin, który składa się z wywiadu, jaki udzielił dr Tomasz Toborek z IPN (współautor Jarocin w...) Cezaremu Gmyzowi, po którym wy-

[17] B. Nichols, op.cit. s 20.

[18] J. Hučkova, Opowieści naocznego świadka. Kino pomiędzy wiosnami Solidarności, [w:] Historia polskie-

\section{Nostalgia. Jarocin $\mathrm{w}$ drugim tysiącleciu}

go filmu dokumentalnego 1945-2014, red. M. Hendrykowska, Poznań 2015, s. 405. 
świetlony jest materiał audiowizualny policji roku 1990. Co ciekawe, wśród materiałów policji znajduje się między innymi wywiad, który wcześniej był wykorzystany w filmie Diabelskie nasienie. Estetycznie, co oczywiste, obydwa obrazy różnią się od rockumentaries, wpisują się za to w konwencję dokumentów o tematyce historycznej: rozmówcy siedzą $\mathrm{w}$ studio na czarnym tle bądź $\mathrm{w}$ archiwum, ich popiersia ukazane są w niskim kluczu oświetlenia. W Wydziale śledczym pojawia się narrator $\mathrm{z}$ offu, w Z filmoteki Bezpieki funkcję tę pełnią napisy pojawiające się na ekranie stylizowane na pisane na maszynie.

Film Dzieci Jarocina (200o) Petro Aleksowskiego rozpoczyna kolejny rozdział w filmografii o festiwalu. Ani forma, ani nawet treść zbytnio się nie zmienia. Inny jest natomiast kontekst: ci sami wykonawcy, których widzieliśmy na filmach z lat osiemdziesiątych, są - choć na różnych etapach kariery - postaciami bardzo rozpoznawalnymi. Twórca przeprowadził wywiady $z$ artystami, między innymi z Pawłem Kukizem, Muńkiem Staszczykiem, Kazikiem Staszewskim i z organizatorami: Walterem Chełstowskim i Kubą Wojewódzkim, którzy, wspominając edycje z lat osiemdziesiątych, zauważają, jak kluczowym wydarzeniem dla polskiej kultury były festiwale, czym okazywały się dla nich prywatnie. Wywiady zmontowane są zarówno z koncertami, jak i z sekwencjami montażowymi ukazującymi festiwalowe życie. Niestety, zabrakło podpisów, z których edycji są to materiały, a informacja w napisach końcowych ogranicza się do wiadomości, że są to archiwalia TVP.

W napisach końcowych do filmu Skansen (2005), opowiadającego o edycji Jarocina z roku 2005, umieszczone są podziękowania dla Andrzeja Wolfa $-z$ dopiskiem, że bez niego film by zapewne nie powstał. W istocie Skansen opiera się na formule dobrze znanej z Fali czy Jarocin 87: rozmowy ze zwykłymi uczestnikami festiwalu zmontowane są wraz z ujęciami z koncertów (podobnie jak w Fali, Skansen kończy ujęcie na dziecko pytane o przyszłość). Większość wykorzystanych utworów między innymi Armii czy Dezertera - a zatem ikon festiwalu sprzed lat jest pokazana w całości. Jeden z rozmówców, nie bez racji, stwierdza, że Jarocin to festiwal buntu, a ciężko się buntować w momencie, kiedy jest się wolnym. W tym kontekście najbardziej wymowny wydaje się sam tytuł filmu...

Jarocin $87-$ podróż $w$ czasie w reżyserii Andrzeja Wolfa, chociaż koprodukowany przez TVP2 i Wielkopolski Fundusz Filmowy, nie figuruje ani w bazie danych „Filmweb”, ani w serwisie „Film Polski”. Pomysł opiera się na przywołaniu fragmentów z filmu Jarocin 87 i poszukiwaniu ich uczestników. Rozmówcami Wolfa są zarówno „weterani” jarocińskich dokumentów: Muniek Staszczyk, Kazik i Tomasz Budzyński, jak i dawni uczestnicy festiwalu, którzy dziś wykonują przeróżne zawody: od sklepikarza poprzez elektryka aż po dyrektorkę szpitala czy byłego prezydenta RP Aleksandra Kwaśniewskiego, który - jak się okazało - bywał w Jarocinie służbowo. Film porusza też kwestie marginalizowane $w$ innych filmach (pewnie jako zbyt oczywiste), jak na przykład kulinaria. W końcówce reżyser pozwolił sobie na dość 
odważną wizję. Oto wizualnym tłem dla utworu Dziwny jest ten świat Czesława Niemena stają się między innymi: zamachy na World Trade Center i tragedia smoleńska.

Jarocin. Po co wolność to bez wątpienia najszerzej zakrojony projekt ze wszystkich omawianych w niniejszym artykule filmów. Jeden z jego twórców - Leszek Gnoiński - jest najpłodniejszym dokumentalistą zainteresowanym polskim rockiem. Nie licząc publikacji książkowych o zespołach Acid Drinkers, Kult, Gnoiński wyreżyserował ośmioodcinkowy serial Historia polskiego rocka, pełnometrażowy dokument: Beats of Freedom: Zew wolności, cykl odcinków serialu poświęconemu Jarocinowi: Wehikut czasu, Wiatr wieje tam gdzie chce, Kobiety karabiny oraz Fugazi. Centrum wszechświata. Każdy z wyżej wymienionych utworów mniej lub bardziej bezpośrednio opowiada o Jarocinie.

Premierze filmu towarzyszyła kampania promocyjna. Dla przykładu: podczas premiery w Opolu zorganizowanej przez Stowarzyszenie Opolskie Lamy wystąpił zespół Armia, w Poznaniu w kinie Rialto zagrał jednoosobowy zespół Brudne Dzieci Sida, po projekcji zaś odbywały się spotkania, podczas których reżyser i muzycy w różnych konfiguracjach zarówno wspominali Jarocin, jak i rozmawiali o dzisiejszej sytuacji muzyki rockowej w Polsce. Twórcom filmu przyświecała idea, aby zaprezentować całą historię festiwalu - od poprzedzającej w latach siedemdziesiątych imprezy Rytmy Młodych aż po współczesność. Ta opowieść o muzyce punk-rockowej mimochodem staje się szkicem socjologicznym o Polsce okresu transformacji. Scena ukazująca, że głównym sponsorem festiwalu zostaje duża firma tytoniowa, jest wymowniejsza niż niejeden artykuł. Najbardziej charakterystyczne dla filmu wydają się sekwencje, podczas których na przedzielonym ekranie widzimy jednocześnie ujęcia archiwalne i współczesne. Tyczy się to samego miasta, ale przede wszystkim koncertów. W recenzji dla „Kina” pisała Jaga Kolawa:

Choć Jarocin. Po co wolność nie ma emocjonalnej siły rażenia i świeżości socjologicznej analizy słynnych dokumentów Fala albo Moja krew, twoja krew ani nie przynosi odkrywczego spojrzenia, jakie dawał film dokumentalny z serii Wydziat śledczy IPN [...] to jednak film Gnoińskiego i Gajczaka jest pozycją obowiązkową. Dla tych dla których Jarocin to odległa legenda, i dla tych, dla których to ciągle przeżycie pokoleniowe[19].

W istocie Jarocin. Po co wolność jest tak skonstruowany, że fan polskiego punk rocka może poukładać swoją wiedzę tudzież poszerzyć o różnego rodzaju ciekawostki, natomiast widz kompletnie niezaznajomiony $\mathrm{z}$ tematem wyniesie $\mathrm{z}$ filmu podstawową wiedzę o polskiej scenie niezależnej lat osiemdziesiątych.

Mirosław Przylipiak, pisząc o filmach rockowych, zauważa, że istotną funkcję pełnią w nich słowa wykorzystywanych piosenek[20].

[19] J. Kolawa, Jarocin. Po co wolność, „Kino” 2016, nr 12, s. 81
[20] M. Przylipiak, Kino bezpośrednie 1963-1970 między obserwacją a ideologią, Gdańsk 2013. s. 120. 
Dokładna analiza utworów prezentowanych w omawianych filmach to obszar na osobne studium (na potrzeby niniejszego artykułu pozwoliłem sobie jedynie na kilka uogólnień). Chciałbym jednakże zwrócić uwagę na interesującą zbieżność: tytuły omawianych filmów bardzo często odnoszą się bezpośrednio do tytułów piosenek granych w Jarocinie. Moja krew, twoja krew - do Republiki; Fala - do utworu Fala grupy Siekiera, która z kolei była jednym z najważniejszych wydarzeń edycji '84. Jarocin. Po co wolność to parafraza refrenu słynnej piosenki grupy Kult. Czapka dla skina - to z kolei ukłon w stronę prześmiewczego utworu grupy Big Cyc.

\section{Podsumowanie}

Ścianę kina Echo w Jarocinie od ponad roku zdobi mural z podobizną Piotra Łazarkiewicza, trzymającego klaps do filmu Fala. Zmarły w 2008 roku reżyser został również patronem działającej przy tym kinie Akademii Filmowej. W kontekście niniejszej pracy bardzo ciekawe jest to, że to właśnie twórca filmowy, a nie żaden muzyk ani organizator został w ten sposób uhonorowany.

Powróćmy do postawionych na początku pytań o styl filmowy i duże zainteresowanie filmowców festiwalem. O dziwo, poza eksperymentalnym filmem Józefa Robakowskiego, twórcy - nie wliczając krótkich sekwencji, drobnych popisów operatorskich - postawili raczej na jasność przekazu niż na zabawę formą. W moim przekonaniu film Jarocin. Po co wolność jest odpowiedzią na deklarację młodzieńców z Dezertera, którzy przekonywali, że powstanie filmu o punk rocku jest niemożliwe. Udział muzyków w promocji filmu może świadczyć o tym, że „podpisują się" pod zaproponowaną przez Gnoińskiego wizją. Niewykluczone, że w przyszłości powstanie jeszcze niejeden dokument, ukazujący festiwal z jeszcze innej perspektywy bądź powtarzający stan wiedzy[21]. W moim odczuciu ciekawym wyzwaniem dla twórców, zważywszy na współczesne tendencje w kinie głównego nurtu oraz w kinie polskim[22], byłoby osadzenie w realiach jarocińskiego festiwalu filmu fabularnego.

Odpowiedzi na tak duże zainteresowanie trzeba szukać w fenomenie samego festiwalu. Na początku był, dosłownie, jedyny w swoim rodzaju. W latach późniejszych, kiedy festiwal w Jarocinie stracił swoją rangę, wciąż żywa jest jego legenda. Dominantą większości omawianych filmów są fragmenty koncertów. Każda edycja to inny zestaw wykonawców, a nawet jeśli wykonawcy się powtarzają - to wracają z innym repertuarem, składem, instrumentarium, co - niezależnie od walorów artystycznych i warsztatu twórców - sprawia, że filmy te będą cieszyć się popularnością, tak długo jak prezentowane w nich zespoły.

[21] W trakcie prac nad wydaniem niniejszego numeru „Images” natrafiłem na jeszcze jeden film poświęcony festiwalowi. Wyświetlany na 23. Festiwalu OFF CINEMA dokument Powracająca Fala (2017) w reżyserii Michała Wiraszki - muzyka znanego z zespołu Muchy, to film oparty na zestawianiu ujęć z Fali z współcześnie przeprowadzonymi wywiadami.
[22] Mam tu na myśli popularność filmów muzycznych (wśród filmów nominowanych w tym roku do Oscara, dominowały fikcyjne - Zimna wojna, Narodziny gwiazdy -i oparte na biografiach opowieści o muzykach - Bohemian Rhapsody, Green Book). A także „modę” na estetykę lat osiemdziesiątych przypomnijmy sobie Ostatnia rodzinę czy serial Rojst. 
Brendan B.M., Rockumentary: Style \& Sound in a Documentary Genre, Montreal 2011

Brylewski R., Księżyk R., Kryzys w Babilonie, Kraków 2012

Hendrykowski M., Słownik terminów filmowych, Poznań 1994

Historia polskiego filmu dokumentalnego (1945-2011), red. M. Hendrykowska, Poznań 2015

Metody dokumentalne w filmie, red. D. Rode, M. Pieńkowski, Łódź 2013

Przylipiak M., Kino bezpośrednie, Gdańsk 2013

Reynolds S., Retromania. Jak popkulultura żywi się własna przeszłościa. przeł. F. Łobodziński, Warszawa 2018

Witkowski K.G., Grunt to Bunt. Rozmowy o Jarocinie, Poznań 2011-2015

\section{Źródła internetowe}

http://czaskultury.pl/czytanki/jarocin-restudy/

http://www.jarocin-festiwal.com

\section{Wybrana filmografia}

Jarocin 82 (1982) reż. Paweł Karpiński

Film o pankach (1983) reż. Mariusz Treliński

Jarocin 84 (1984) reż. Andrzej Królak

Po drugiej stronie rampy (1984) reż. Wiesław Szlachciak

To tylko rock (1984) reż. Paweł Karpiński

Fala (1985) reż. Piotr Łazarkiewicz

Moja krew, twoja krew (1986) reż. Andrzej Kostenko

Tilt. Moje Oko (1986) Robakowski

Jarocin '87 (1987) reż. Andrzej Wolf

Diabelskie Nasienie (1990) reż. Franciszek Trzeciak.

Czapka dla skina (1991) reportaż telewizyjny

Przestań się lękać. Jarocin 1991 (1991) reportaż telewizyjny

Dzieci Jarocina (2000) reż. Petro Aleksowski

Skansen (2006) reż. Rafał Żurek

Wydział śledczy IPN: Jarocin (2008) reż. Marian Więcław

Jarocin - historia rockiem pisana, czyli 30 lat festiwalu (2010) reż. Dorota Tuńska

Podróż w czasie. Jarocin 1987 (2014) reż. Andrzej Wolf

Jarocin. Po co wolność (2016) reż. Leszek Gnoiński

Powracająca Fala (2017) reż. Michał Wiraszko

\section{Odcinki seriali}

Historia polskiego rocka, (2008) odc. Ku przyszłości reż. Leszek Gnoiński

Dziewczyny karabiny; Wiatr wieje tam gdzie chce, Wehikuł Czasu (2013) reż. Leszek Gnoiński, Wojciech Słota

IPN TV Z filmoteki Bezpieki (2014) odc. 9 Jarocin reż. Cezary Gmyz 